\title{
Infectivity of Infectious Bursal Disease Virus Neutralized by Maternal Antibody in Various Chicken Cells
}

Ken-ichi KOMINE, Hiroaki OHTA, ${ }^{1)}$ Shin-ichi KAMATA, ${ }^{1)}$ Kazuo UCHIDA, and ${ }^{2)}$ Katsuya HIRAI . Ghen Corporation, Oritate 296-1, Gifu, Gifu 501-11, ${ }^{1)}$ Department of Veterinary Hygiene, Division of Veterinary Medicine, Nippon Veterinary and Zoo-technical College, Musashino, Tokyo 180, and ${ }^{2)}$ Department of Veterinary Microbiology, Faculuty of Agriculture, Gifu University, Yanagido 1-1, Gifu, Gifu 501-11, Japan (Received 21 December 1987/Accepted 17 January 1989)

Jpn. J. Vet. Sci. 51(3): 634-635, 1989

KEY WORDS: chicken macrophage, IBD virus, infectivity.

The specific antibody to infectious bursal disease virus (IBDV) has been reported to play an important role in the defense mechanism of chickens against infections [5]. However, very few studies on the neutralizing antibody to IBDV using the natural target cell system have been conducted. In this study, infectivity of IBDV after neutralization by the maternal antibody in chicken embryo (CE) cells, spleen adherent cells, spleen lymphocytes, or, LSCC-1104-X-5 or LSCC-1104-B-1 line cells [4] was investigated.

The J1 strain of IBDV passaged in CE cells [6] was adjusted to $10^{2.5}$ median tissue culture infective dose $\left(\mathrm{TCID}_{50}\right)$ per $\mathrm{m} l$. Primary monolayer culture of $\mathrm{CE}$ cells was prepared from 10- to 11-day-old specific-pathogen-free (SPF) chicken embryos and spleen cells were prepared from 3-week-old SPF chickens. Adherent cells and lymphocytes were further separated from the spleen cells. Some of the spleen cells were incubated in glass dishes at $37^{\circ} \mathrm{C}$ for $2 \mathrm{hr}$. The cells attaching on the dishes were harvested and designated as spleen adherent cells. The other spleen cells were separated by low speed centrifugation with lymphocyte-separate-solution (Sigma Chemical Co., St Louis, MO.) and used for spleen lymphocytes. Two B line cells were also used in this experiment. Culture medium of RPMI 1640 supplemented with $5 \%$ fetal bovine serum was used for spleen cells and two B line cells, while Eagle's minimum essential medium with $3 \%$ fetal bovine serum was used for $\mathrm{CE}$ cells. A total of 80 - to 100-day-old hens from Fukuyama Parent Chicken Farm (Fukuyama city) were immunized by IBDV killed vaccine and raised. Day-old chickens derived from these hens were bled. Serum was separated from the blood and pooled. Pooled serum was designated as maternal neutralizing antibody (MN-Ab). The $\mathrm{MN}-\mathrm{Ab}$ measured by $50 \%$ plaque reduction method was found to be 4,477 units.

The MN-Ab was subsequently diluted to 150 units with culture medium. Normal serum prepared from 3 week-old SPF chickens was used as control. The antibody titer of the control serum after heat-inactivated at $56^{\circ} \mathrm{C}$ for $30 \mathrm{~min}$ was less than 4 units. IBDV was mixed with an equal volume of diluted $\mathrm{MN}-\mathrm{Ab}$, control serum and culture medium and incubated at $37^{\circ} \mathrm{C}$ for $1 \mathrm{hr}$. After incubation, the samples were diluted ten times with culture medium. A quantity of $0.1 \mathrm{ml}$ of the three samples was each inoculated into the $\mathrm{CE}$ cells, spleen cells and line cells, respectively. After incubation at $37^{\circ} \mathrm{C}$ for 4 days, the infective titers of the culture supernatants were measured in the CE cells.

No measurable infectivity of IBDV in the culture supernatant of LSCC-1104-X-5 cells, LSCC-1104-B-1 cells or spleen lymphocytes was detected after neutralization by $\mathrm{MN}-\mathrm{Ab}$ (Table 1). The results were similar to those of CE cells. However, the infectivity of IBDV in the culture supernatant of the spleen adherent cells was $10^{3.3}$ TCID $_{50} / \mathrm{m} l$. On the other hand, IBDV treated with control serum or culture medium retained infectivity to these cells.

Specific antibody to IBDV has been considered to be stimulated either by the virus infection or vaccination with live or killed vaccines. It is advisable to keep appropriate levels of maternal antibody for the protection of young chickens against field IBDV exposure [5]. The antibody responses can be measured by several methods. In this experiment, the standard neutralization test used was a combination of the serum and IBDV. Therefore, postneutralization infectivity of IBDV in CE cells, chicken spleen cells and B line cells was examined.

Table 1 clearly demonstrates that $\mathrm{MN}-\mathrm{Ab}$ inhibits the infectivity of IBDV in spleen lymphocytes and B line cells as well as in CE cells. However, the inhibitory activity of $\mathrm{MN}-\mathrm{Ab}$ was not observed in spleen adherent cells. Several 
Table 1. Virus growth of $\mathbf{J} 1$ strain of IBDV in various chicken cells after neutralization

\begin{tabular}{lccc}
\hline \multirow{2}{*}{ Incubated into } & \multicolumn{3}{c}{ Virus growth after neutralized by } \\
\cline { 2 - 4 } & MN-Ab & Control serum & Culture medium \\
\hline CE cells & $<1.5^{\text {a) }}$ & 4.8 & 6.5 \\
Spleen lymphocytes & $<1.5$ & 4.3 & 4.8 \\
Spleen adherent cells & 3.3 & 3.5 & 3.3 \\
LSCC-1104-X-5 & $<1.5$ & 4.8 & 5.5 \\
LSCC-1104-B-1 & $<1.5$ & 3.8 & 4.0 \\
\hline
\end{tabular}

a) Less than $1.5\left(\log \mathrm{TCID}_{50}\right)$.

Figures indicate titers in $\log \mathrm{TCID}_{50} / \mathrm{ml}$ in CE cells.

studies have demonstrated that neutralizing antibody inhibits the binding of viruses by preventing attachment to the receptor of the susceptible cells. Although IBDV receptor of CE cells was not known, the result of this study indicates that the binding site of IBDV to CE cells was blocked by $\mathrm{MN}-\mathrm{Ab}$. Therefore, the attachment of neutralized IBDV to the adherent cells was always observed. Similar phenomena had been reported in some viruses including Dengue and canine distemper viruses $[1,2,3]$. In these viruses, that the virus-antibody complex was found to be infectious for macrophages or $\mathrm{Fc}$ receptor cells. With respect to these cases, one possible explanation is that IBDV found to the MN-Ab infects the adherent cells via the process of phagocytosis. Another possibility is that IBDV bound to $\mathrm{MN}-\mathrm{Ab}$ infects the $\mathrm{Fc}$ receptor cells. Research on the mechanisms of the receptorindependent infection of the neutralized IBDV is now in progress.

REFERENCES

1. Appel, M. J. G., Mendelson S. G., and Hall, W. W. 1984. J. Virology. 51: 643-649.

2. Brandt, W. E., McCown, J. M., Gentry, M. K., and Russell, P. K. 1982. Infect. Immun. 36: 1036-1041.

3. Halstead, S. B. and O'Rourke, E. J. 1977. Nature (London). 265: 739-741.

4. Hihara, H., Shimizu, T., and Yamamoto, H. 1974. Natl. Inst. Anim. Health. Q. (Jpn). 14: 163-173.

5. Lukert, P. D. and Hitcher, S. B. 1984. Infectious bursal disease. PP. 565-576. In: Disease of Poultry, 8th ed. (Hofstad, M. S., Barnes, H. J., Calneck, B. W. and Yorder Jr, H. W. eds.) Iowa State Univ. Press, Ames.

6. Yamaguchi, S., Imada, T., and Kawamura, H. 1981. Avian Dis. 25: 927-935.

要 約

中和された伝染性ファブリキウスのう病ウイルス（IBDV）の各種ニワトリ細胞に拈ける感染性（短報）： 小峯健一・大田博昭・鎌田信一王) -内田和夫 ${ }^{1)}$ ・平井克哉 ${ }^{2)}\left((\right.$ 株 $)$ ゲン・コーポレーション, ${ }^{1)}$ 日本獣医畜産大 学獣医畜産学部獣医衛生学教室, ${ }^{2)}$ 岐阜大学農学部家畜微生物学教室) - - IBDV・J 1 株を, IBDVに対する移 行抗体保有 1 日齢ヒナ血清で中和した。この中和ウイルスを，3 週龄のSPFヒナの脾細胞より調整したガラス デッシュ付着細胞，リンパ球，鶏胚線維芽細胞およびニワトリ腫瘍株化細胞（LSCC-1104-X-5，LSCC-1104-B1 細胞）にそれぞれ接種し，その増殖を調べたところ，ウイルスの増殖はガラスデッシュ付着細胞でのみ認めら れた。この結果から，マクロファージ様細胞では中和されたウイルスが，IBDV 特異レセプターを介さずに感染 する事が示唆された。 